\title{
FINANCING THE GREENING OF ENTERPRISES IN INDUSTRIAL REGIONS OF UKRAINE IN THE CONTEXT OF SUSTAINABLE DEVELOPMENT
}

\author{
Olga Laktionova ${ }^{1}$, Zhanna Harbar ${ }^{2}$, Andriy Melikhov', Olha Slobodianiuk ${ }^{3}$, Volodymyr Gevko ${ }^{4}$, \\ Sergii Desiatskyi ${ }^{1}$
}

\begin{abstract}
${ }^{1}$ State Higher Educational Institution “Priazovskyi State Technical University”, Universytetska 7, Mariupol, 87555, Ukraine
\end{abstract}

${ }^{2}$ Vinnytsia National Agrarian University, 3 Pirogova St., Vinnytsia, 2100, Ukraine

${ }^{3}$ National University “Odessa Law Academy”, 54 Akademichna St., Odessa, 65009, Ukraine

${ }^{4}$ Western Ukrainian National University, 11 Lvivska St., Ternopil, 46009, Ukraine

Received 0811 2021; Accepted 09112021

\section{Abstract}

The work is devoted to the study of improving the environmental situation in industrial regions with metallurgical production in Ukraine. It was revealed that monitoring and purification of air, water environment and land resources requires immediate development and implementation of greening projects. This requires finding additional financial resources that are lacking in local budget deficits. To improve the quality of formation and use of local budgets, a method of monitoring the revenue side of local budgets is proposed, which consists in processing a set of data imported from monthly revenues and processed using predictive analytics tools. The methodology allows to identify significant and insignificant factors in a timely manner, including the environmental tax in the resulting factor - local budget revenues. With the development of analytical systems and the expansion of their application in the greening of industrial regions, the developed methodology will not lose its relevance. The developed methodology for monitoring the environmental tax and other taxes, fees and charges is aimed at identifying additional (indirect) sources of funding for greening projects in industrial regions, including metallurgical production. The method was tested on the revenues of local budgets of cities with metallurgical production - Zaporizhzhya, Dnipro for the period 2018-2020. The use of the methodology allowed to show that the revenues of the environmental tax are the most insignificant. It is also proposed to use the experience of developed countries in the mechanism of calculating the environmental tax in order to increase its amount.
\end{abstract}

Keywords: ecological tax, greening projects, local budgets, metallurgical industry.

JEL Classification: H7, H20, O47.

\section{Introduction}

The task of greening regions with metallurgical production is to prevent emissions, monitor and clean the air, water environment and land resources from harmful inclusions. In the metallurgical industry of Ukraine, the output of waste exceeds the output of the target product by 6-7 times (Glushchenko, 2021). Considering the crisis phenomena in the economy of Ukraine, the issues of development of greening projects, including innovative technologies for cleaning the atmosphere, processing of industrial waste are especially relevant (Mikelsone et al., 2021). In this regard, the search for sources of funding for the development and implementation of projects for the greening of industrial regions of Ukraine is relevant, especially in the context of acute budget

Copyright (C) 2021 Author(s), published by Vytautas Magnus University. This is an open access article distributed under the terms of the Creative Commons Attribution Non-Commercial 4.0 (CC BY-NC 4.0) license, which permits unrestricted use, distribution, and reproduction in any medium provided the original author and source are credited. The material cannot be used for commercial purposes. 
deficits of emerging communities. These projects will be aimed not only at improving the ecology of the regions, but also at increasing the economic efficiency of this production (Meshram, Pandey, 2019; Kostetska et al., 2021). Some of the projects aimed at waste disposal will expand the resource base of metallurgy for many types of scarce raw materials, such as expensive alloying and rare earth metals.

Bolshina (2012) considered ways to improve the environmental and economic efficiency of metallurgical production.
Components of emissions from metallurgical production are presented in table 1. The largest amount of emissions is in coke production. In addition to these pollutants, we can note pyridine bases, aromatic hydrocarbons, phenols, ammonia, 3-4\%benzopyrene, hydrocyanic acid and others.

In world practice, the share of ferrous metallurgy enterprises accounts for $15-20 \%$ of total air pollution by industry, which is 3 million tons of harmful substances per year, and areas of large metallurgical plants - up to $50 \%$ (Glushchenko, 2021).

Table 1. The main components of emissions from metallurgical production $[1,2]$

\begin{tabular}{|c|c|c|c|c|}
\hline $\begin{array}{c}\text { Emission } \\
\text { components }\end{array}$ & $\begin{array}{c}\text { Sinter } \\
\text { production, } \\
\text { kilog. / t. }\end{array}$ & $\begin{array}{c}\text { Blast furnace } \\
\text { production, } \\
\text { Kilog. / t. }\end{array}$ & $\begin{array}{c}\text { Steel } \\
\text { production, } \\
\text { kilog./ t. }\end{array}$ & Rolling production \\
\hline Dust & $20-25$ & $100-106$ & $13-32$ & $0.7-0.2 \mathrm{kil} . / \mathrm{t}$. of rolled metal \\
\hline Carbon monoxide & $20-50$ & $600-605$ & $04,-0,6$ & $0.7 \mathrm{t} / \mathrm{m}$. of metal surface \\
\hline Sulfur oxide & $3-25$ & $0,2-0,3$ & $0,4-35$ & $0.4 \mathrm{t} / \mathrm{m}$. of metal surface \\
\hline Nitric oxide & & & $0,3-3,0$ & $0.5 \mathrm{t} / \mathrm{m}$. of metal surface \\
\hline
\end{tabular}

In order to develop and implement projects aimed at greening industrial regions, especially regions with metallurgical production, it is necessary to identify sources of funding, including indirect funding. According to the Tax Code of Ukraine (2014), one of the sources of funding for greening projects of industrial regions with metallurgical industry in Ukraine may be an environmental tax, which must be paid by all legal entities, if their activities lead to: emissions of harmful substances into the air, including carbon dioxide; discharge of harmful substances into rivers, ponds, lakes, canals, reservoirs, seas or groundwater;

Environmental tax rates, depending on the type of harmful substance, are presented in the Tax Code of Ukraine and depend on the amount of harmful substance (in tons) that enters the air, watercourses or reservoirs. The procedure for calculating each type of pollution or type of harmful substance is as follows. Thus, the amount of tax levied for emissions of pollutants into the atmosphere by stationary sources of pollution, are calculated based on the actual emissions, tax rates by the formula (Tax Code of Ukraine, 2014):

$$
P_{V C}=\sum_{i=1}^{n}\left(M_{i} * H_{n i}\right)
$$

Where: $M_{i^{-}}$is the actual emission of the $\mathrm{i}$-th pollutant in tons $(\mathrm{t}) ; H_{n i}$ - is the tax rate in the current year per ton of the i-th pollutant.

The amount of tax levied for the discharge of pollutants into water bodies (Ps) is calculated quarterly based on the actual amount of discharges, tax rates and adjustment factors by the formula (Tax Code of Ukraine, 2014):

$$
P_{C}=\sum_{i=1}^{n}\left(M_{n i} * H_{n i} * K_{o c}\right)
$$

Where: $M_{n i}$ - is the volume of discharge of the $\mathrm{i}$-th pollutant in tons $(\mathrm{t})$;

$H_{n i}-$ tax rates in the current year per ton of the i-th type of pollutant;

$K_{o c}$ - is a factor that is equal to 1.5 and is used in the case of discharge of pollutants into ponds and lakes. 


\section{Related works}

The concept of "environmental tax" in EU countries includes (Korshunov et al., 2012): energy taxes (on coal, petroleum products, electricity, etc.); transport taxes (payments for imports, operation, recycling, sale of vehicles); taxes for environmental pollution (for emissions of pollutants into the atmosphere and water resources); minerals, special water use, etc.).

In EU countries, the main part of environmental tax revenues is formed by energy taxes $-76.9 \%$. In Ukraine, $100 \%$ of the environmental tax is payments for environmental pollution. The purpose of environmental taxes is to help reduce the negative impact of business activities on the environment. This goal can be achieved in two forms. The first approach is to set high rates of environmental taxes. In this case, companies will prefer to implement environmental measures to reduce the cost of paying environmental taxes. As a result, the negative impact on the environment will be reduced. The second approach to the use of environmental taxes is to finance environmental measures that can compensate for environmental pollution. In this case, the higher the share of environmental tax used to cover environmental costs, the more efficiently the funds are used (Kvach, Piatka, Koval, 2020).

The collected amounts of environmental tax do not meet the requirements of the environmental situation in industrial regions, including metallurgical production. Thus, in 2017, Ukraine collected 1.7 billion UAH of environmental tax in the state budget, and environmental measures were financed in the amount of 2.8 times more ( 4.7 billion $\mathrm{UAH}$ ) (Glushchenko, 2021).

At $1.1 \%$ of ecological tax revenues were used to finance environmental protection expenditures in Donetsk oblast, $11.9 \%$ in Dnipropetrovsk oblast, and in Zaporizhzhya oblast the efficiency of ecological tax use is close to zero (Glushchenko, 2021). According to Database on Policy Instruments for the
Environment, collected by the Organization for Economic Cooperation and Development, the environmental subsidy mechanism in force in the European Union includes: grants; tax rebates; soft loans (Filin et al., 2018). There are no such environmental financing instruments in Ukraine, and the funds are distributed within budget programs. Implemented measures are remotely related to environmental protection.

Thus, in Krivoy Rog the proceeds of the environmental tax were used to conduct research and substantiate measures to control quarantine plants, in Zaporizhzhya for the reconstruction of sewers and clearing the reservoir in the city park, in Lviv region - to develop documentation for peat extraction. However, most of the works reveal only some aspects of the research topic, and therefore, there is no doubt about the need for further study.

Due to the creation of conditions for innovative activity for industrial enterprises, industrial regions were able to pursue environmental policies (Dotsenko, Ezdina, Mudrova, 2018). Environmental taxation and the use of environmental assets in Ukraine and the EU have common problems with shortcomings: the inefficiency of the organization of budget revenue collection; with a lack of transparency and inefficient use of environmental tools (Jishkariani, 2010; Saxena, Kumar, 2020). Problems are added inefficiencies in the formation and use of local budgets, which are mostly deficient. In Ukraine, problems of inefficient use of extracted natural resources on the principle of "extracted-processed-discarded" are added. This happens when the methods and principles of innovative methods of economic management - circular economy - are introduced in world practice (Kostetska, Smol, Gaska, 2018; Gubanova et al., 2019; Zhang, Zhang, Wu, Liu, 2021). 


\section{Methods}

Improving the environmental situation in industrial regions with metallurgical production is associated with the search for additional - indirect sources of funding. For this, the authors propose to process datasets formed from monthly receipts of Openbudget, Opendata. Using the correlation analysis toolkit, the authors found that tax revenues to local budgets of Ukraine are insignificant. The most insignificant is the environmental tax in the revenues of local budgets. The amount of the environmental tax is insignificant for financing projects for the greening of regions with metallurgical production. The most urgent project at the present time is the development of a project for an installation for monitoring and purifying atmospheric air. The project requires additional funding, which is not provided for in the plans of metallurgical plants. The proposed data processing toolkit for Openbudget (Zaporizhzhia City Council, 2021; Dnipro City Council, 2021) and
Opendata allows for timely adjustment of the significance of factors - tax revenues to the budgets of the united territorial communities being formed. It is known that the united territorial communities of Ukraine are in dire need. However, with the advent of Openbudget data, Opendata has an opportunity to improve the quality of local budget management. Timely adjust the indicators of input factors (revenues) in the resulting factor - the total revenues of local budgets. To monitor the revenue side of local budgets, the authors used modern analytical systems.

\section{Results and Discussion}

Datasets were imported from monthly Openbudget receipts for cities with metallurgical production - Zaporizhzhya, Dnipro. It was revealed that the environmental tax in Zaporizhzhya has an insignificant value and weak growth dynamics over the years (Fig. 1).

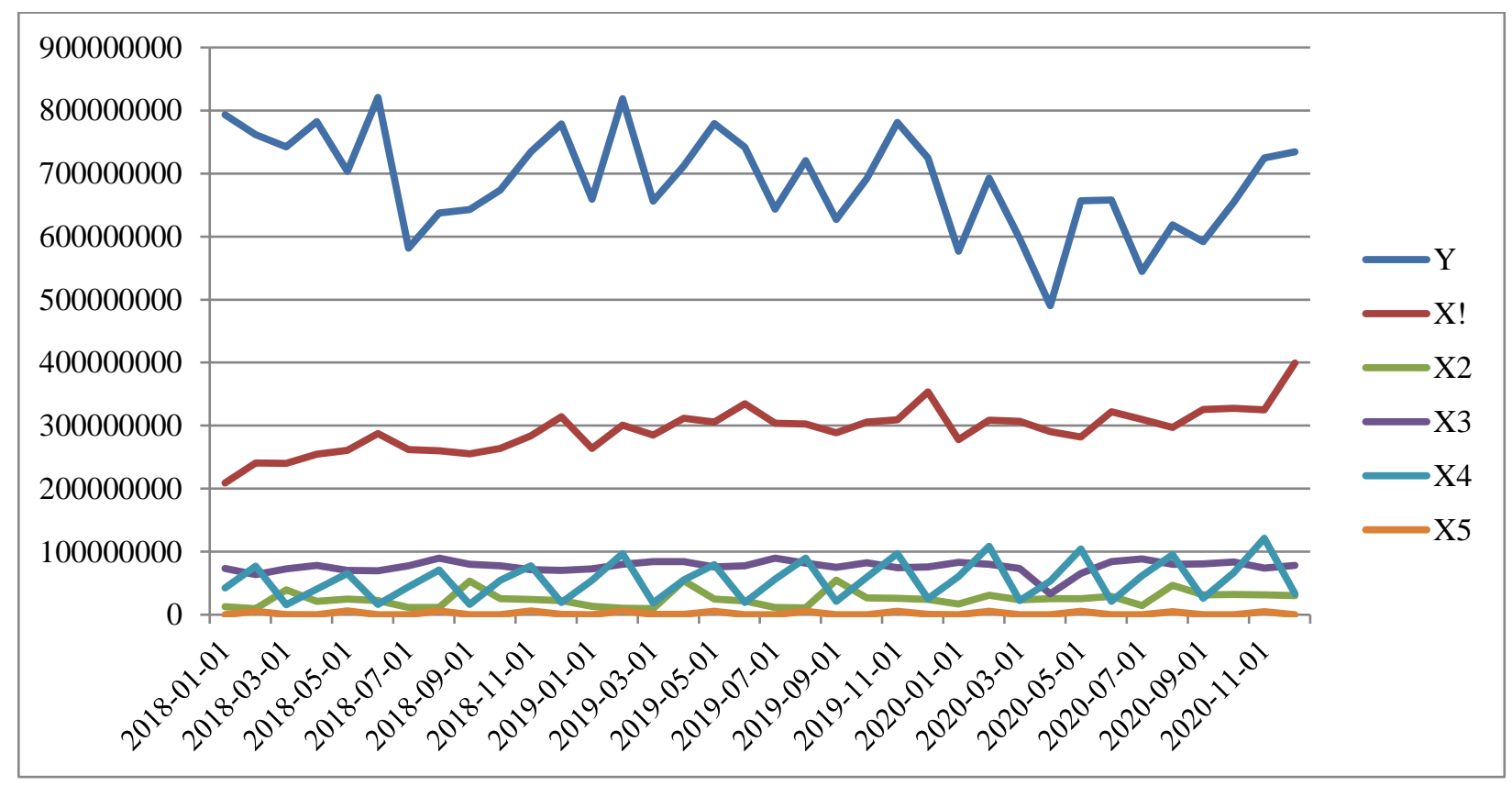

Y-all income to the budget of Zaporizhzhia; X1-tribute from income of physical persons. X2-excise tax; X3-tribute for mineo; X4 - One tribute; X5 - ecological tax.

Figure 1. Dynamics of ecological tax (X5) at the budget of the city of Zaporizhzhia, 2018-2020, hryvnia 
The environmental tax (X5) is the smallest in the revenues of local budgets of the city of Zaporozhye for the period 2018-2020. To finance projects on the greening of Zaporizhzhya, there is a need for an increase in the cost of an ecological tax to the budget (Fig. 1). There are several ways to increase the environmental tax: increase the rates of the environmental tax; change the formula for calculating the environmental tax. The proposed methodology makes it possible to monitor revenues, including the environmental tax, to local budgets. The results of monitoring the local budget of the city of Zaporizhzhya are presented in Table 1 and in Fig. 2.

For the organization of monitoring for the appropriate ecologic tribute, in proportion to the incomes of the budget, the budget for the months will be promoted to victorious methods of predictive (predictive) analysis. The value of the ecological tribute and the profitable need for the profitable part of the budget, please, look for the formula (Draper, Smith,2007):

$$
r_{x y}=\frac{\sum\left(x_{i}-\bar{x}\right)\left(y_{i}-\bar{y}\right)}{\sqrt{\sum\left(x_{i}-\bar{x}\right)^{2} \sum\left(y_{i}-\bar{y}\right)^{2}}}
$$

where: $x_{i}$ - the value of the variable $\mathrm{X}$; $y_{i^{-}}$the value of the variable $\mathrm{Y} ; \bar{x}-$ the arithmetic mean of the variable X; $\mathrm{y}$ - the arithmetic mean of the variable $\mathrm{Y}$.

In order to optimize the calculations, formula (3) takes the following form (Draper, Smith,2007):

$$
r_{x y}=\frac{n \sum x y-\left(\sum x\right)\left(\sum y\right)}{\sqrt{\left[n \sum x^{2}-\left(\sum x\right)^{2}\right]\left[n \sum y^{2}-\left(\sum y\right)^{2}\right]}}
$$

The results of the projects are presented in Table 1. - a matrix of correlation factors (X1-X5) with the budget revenues (Y) in Zaporizhzhya for the development of sources of additional (indirect) financing of environmental projects, 2018-2020 (Table 1).

Table 1. Matrix of the correlation factor - ecological tax (X5) with budget revenues in Zaporizhzhya, 2018-2020

\begin{tabular}{|l|l|l|l|l|l|}
\hline & \multicolumn{1}{|c|}{$\mathbf{X 1}$} & \multicolumn{1}{|c|}{$\mathbf{X 2}$} & \multicolumn{1}{|c|}{$\mathbf{X 3}$} & \multicolumn{1}{|c|}{$\mathbf{X 4}$} & \multicolumn{1}{|c|}{$\mathbf{X 5}$} \\
\hline $01.01 .2018-01.01 .2019$ & 0,038169541 & $-0,11055486$ & $-0,61219644$ & $-0,2184213$ & $-0,12295$ \\
\hline $01.01 .2018-01.02 .2019$ & 0,030171363 & $-0,05168681$ & $-0,57262106$ & $-0,2379922$ & $-0,07288$ \\
\hline $01.01 .2018-01.03 .2019$ & 0,171861976 & $-0,14431357$ & $-0,43217762$ & 0,00306058 & 0,079316 \\
\hline $01.01 .2018-01.04 .2019$ & 0,114195424 & $-0,07880786$ & $-0,47762688$ & 0,07321552 & 0,118469 \\
\hline $01.01 .2018-01.05 .2019$ & 0,093385024 & $-0,07906577$ & $-0,45799575$ & 0,07100624 & 0,120939 \\
\hline $01.01 .2018-01.06 .2019$ & 0,153310408 & $-0,07097338$ & $-0,44942669$ & 0,12703074 & 0,180609 \\
\hline $01.01 .2018-01.07 .2019$ & 0,165922882 & $-0,07208998$ & $-0,44279794$ & 0,10402955 & 0,166287 \\
\hline $01.01 .2018-01.08 .2019$ & 0,099076848 & $-0,01668211$ & $-0,49947278$ & 0,08045311 & 0,201624 \\
\hline $01.01 .2018-01.09 .2019$ & 0,098262364 & $-0,01741263$ & $-0,49192205$ & 0,07736423 & 0,194495 \\
\hline $01.01 .2018-01.10 .2019$ & 0,068603987 & $-0,15608888$ & $-0,4547481$ & 0,14201696 & 0,230554 \\
\hline $01.01 .2018-01.11 .2019$ & 0,052629095 & $-0,15894883$ & $-0,45918921$ & 0,1349458 & 0,238186 \\
\hline $01.01 .2018-01.12 .2019$ & 0,094026797 & $-0,14695876$ & $-0,46415012$ & 0,19847022 & 0,279557 \\
\hline $01.01 .2018-01.01 .2020$ & 0,095066202 & $-0,14657302$ & $-0,46463832$ & 0,18962757 & 0,273387 \\
\hline $01.01 .2018-01.02 .2020$ & 0,100488288 & $-0,09402487$ & $-0,49357044$ & 0,14312668 & 0,304412 \\
\hline $01.01 .2018-01.03 .2020$ & 0,090737962 & $-0,09915388$ & $-0,49556234$ & 0,11011543 & 0,282203 \\
\hline $01.01 .2018-01.04 .2020$ & 0,043099644 & $-0,09412132$ & $-0,43119522$ & 0,16645125 & 0,30931 \\
\hline $01.01 .2018-01.05 .2020$ & 0,01966745 & $-0,09322085$ & 0,19190186 & 0,13955355 & 0,334406 \\
\hline
\end{tabular}


Olga Laktionova, Zhanna Harbar, Andriy Melikhov, Olha Slobodianiuk, Volodymyr Gevko, Sergii Desiatskyi Financing the greening of enterprises in industrial regions of ukraine in the context of sustainable development

\begin{tabular}{|l|l|l|l|l|l|}
\hline $01.01 .2018-01.06 .2020$ & 0,021321516 & $-0,09488293$ & 0,20526797 & 0,09886257 & 0,302097 \\
\hline $01.01 .2018-01.07 .2020$ & 0,000638677 & $-0,10093006$ & 0,18714963 & 0,11492464 & 0,31027 \\
\hline $01.01 .2018-01.08 .2020$ & $-0,045063746$ & $-0,05099684$ & 0,09915529 & 0,09024908 & 0,332598 \\
\hline $01.01 .2018-01.09 .2020$ & $-0,054018642$ & $-0,09775077$ & 0,0870686 & 0,04651311 & 0,291354 \\
\hline $01.01 .2018-01.10 .2020$ & $-0,09619172$ & $-0,11597883$ & 0,06943813 & 0,07956764 & 0,308555 \\
\hline $01.01 .2018-01.11 .2020$ & $-0,108310986$ & $-0,12176541$ & 0,05987931 & 0,07389358 & 0,313728 \\
\hline $01.01 .2018-01.12 .2020$ & $-0,089729241$ & $-0,11304027$ & 0,05617578 & 0,09934362 & 0,322905 \\
\hline
\end{tabular}

The values of the correlation coefficient of the environmental tax (X5) with revenues to the local budget of Zaporizhzhya for the period 2018-2020 (Table 1, Fig. 2) are insignificant compared to other $(\mathrm{X} 1, \mathrm{X} 2, \mathrm{X} 3, \mathrm{X} 4)$ taxes, fees and charges.

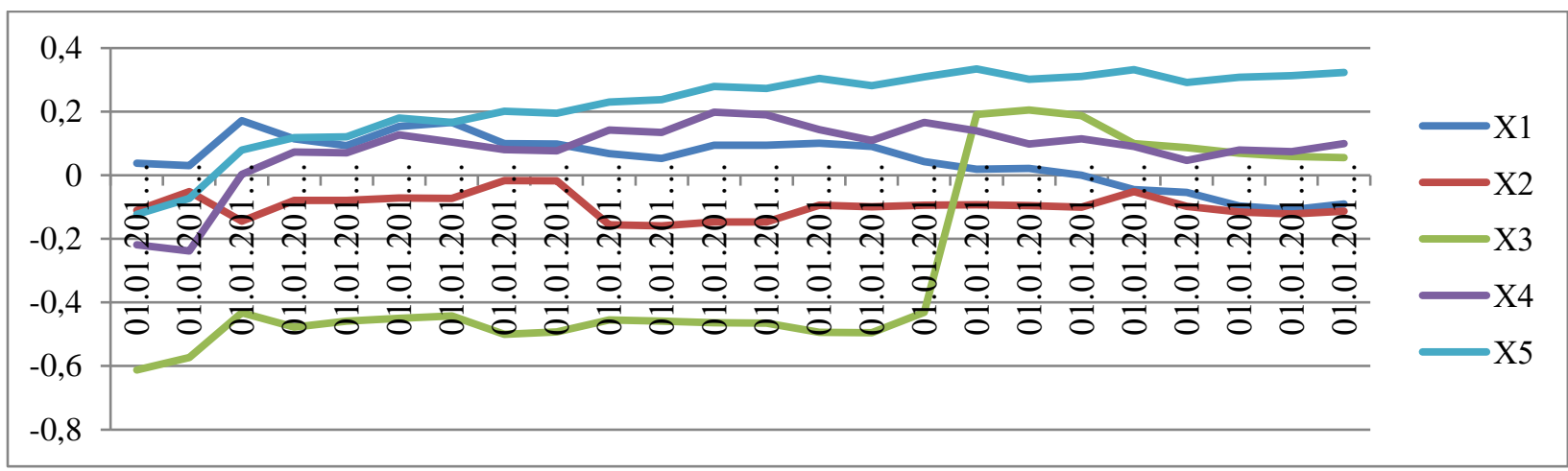

Figure 2. Dynamics of Pearson's correlation coefficients between environmental tax revenues and local budget revenues in Zaporizhzhya, 2018-2020

The dynamics of the Pearson correlation coefficient between the environmental tax, tax revenues and the total values of all revenues to the budget of Zaporizhzhya is insignificant (Fig. 2, Table 1). There is a need to change the mechanism for calculating the environmental tax and the size of rates.

Table 2. Revenues of the environmental tax (X5) to the local budget revenues of the city of Dnipro, 2018-2020, hryvnias

\begin{tabular}{|c|c|c|c|c|c|l|}
\hline & \multicolumn{1}{|c|}{$\mathbf{Y}$} & \multicolumn{1}{|c|}{ X1 } & \multicolumn{1}{|c|}{ X2 } & \multicolumn{1}{|c|}{ X3 } & \multicolumn{1}{c|}{ X4 } & \multicolumn{1}{|c|}{ X5 } \\
\hline 01.01 .2018 & 941455901 & 296006058 & 23841022 & 135698515 & 104660353 & 48689 \\
\hline 01.02 .2018 & 1048435728 & 341758399 & 17726550 & 96568560 & 162033251 & 4008205 \\
\hline 01.03 .2018 & 1049484996 & 353954021 & 57877139 & 112354124 & 31994442 & 4871 \\
\hline 01.04 .2018 & 1362651107 & 359872041 & 33679822 & 180820082 & 90150617 & 78867 \\
\hline 01.05 .2018 & 1048338982 & 356743707 & 38398558 & 120331797 & 134712812 & 5989220 \\
\hline 01.06 .2018 & 1032015188 & 411631273 & 36453875 & 128432310 & 33235450 & 14541 \\
\hline 01.07 .2018 & 956986515 & 401985740 & 21103126 & 158027333 & 102124566 & 46891 \\
\hline 01.08 .2018 & 1129791963 & 373554191 & 21698121 & 135434412 & 141850509 & 4173884 \\
\hline 01.09 .2018 & 973781601 & 373432709 & 79108458 & 142614208 & 36189050 & 4034 \\
\hline 01.10 .2018 & 1086597344 & 384324355 & 40779166 & 175793777 & 114130489 & 76336 \\
\hline 01.11 .2018 & 1257637159 & 391334976 & 39594378 & 155952305 & 162603866 & 3928975 \\
\hline 01.12 .2018 & 1216239417 & 484891763 & 36393831 & 145559633 & 44871325 & -111 \\
\hline 01.01 .2019 & 1011630315 & 374359259 & 24683785 & 162048075 & 126107131 & 205990 \\
\hline 01.02 .2019 & 1267934726 & 418202261 & 18944652 & 157518378 & 200960418 & 5553408 \\
\hline
\end{tabular}


Management Theory and Studies for Rural Business and Infrastructure Development eISSN 2345-0355. 2021. Vol. 43. No. 4: 574-584

Article DOI: https://doi.org/10.15544/mts.2021.52

\begin{tabular}{|c|c|c|c|c|c|c|}
\hline 01.03 .2019 & 1125117563 & 418366637 & 18388210 & 190503537 & 36637989 & 29893 \\
\hline 01.04 .2019 & 1192153899 & 450121702 & 75811382 & 157969921 & 121913641 & 209053 \\
\hline 01.05 .2019 & 1323030359 & 461519731 & 38194793 & 131215702 & 165837977 & 5657843 \\
\hline 01.06.2019 & 1208381487 & 501163246 & 34984275 & 130954613 & 38787667 & -3103 \\
\hline 01.07.2019 & 1116063506 & 473505434 & 22166362 & 177743858 & 134473453 & 56973 \\
\hline 01.08 .2019 & 1160818938 & 459949015 & 22127879 & 138608236 & 167249009 & 5478106 \\
\hline 01.09.2019 & 1198531696 & 466229327 & 75251567 & 131067840 & 43578710 & 34493 \\
\hline 01.10 .2019 & 1161046545 & 473301943 & 41589057 & 163913867 & 132841533 & 53062 \\
\hline 01.11 .2019 & 1190162516 & 472814436 & 41392527 & 134874067 & 188157204 & 4044016 \\
\hline 01.12 .2019 & 1097258832 & 603079867 & 38221455 & 130841535 & 53118854 & 50957 \\
\hline 01.01 .2020 & 1155739139 & 461062284 & 31371481 & 159848490 & 147286086 & 53908 \\
\hline 01.02 .2020 & 1139619064 & 498898983 & 45910037 & 139542705 & 219872877 & 3403716 \\
\hline 01.03 .2020 & 999887489 & 485886786 & 36799992 & 119984670 & 43545398 & 3461 \\
\hline 01.04 .2020 & 843859233 & 452155038 & 39372397 & 49913652 & 122095289 & 60728 \\
\hline 01.05 .2020 & 1089618587 & 427751279 & 39373213 & 104751550 & 180250832 & 3253032 \\
\hline 01.06 .2020 & 1134286954 & 508093255 & 45671385 & 176693799 & 41776733 & 4287 \\
\hline 01.07 .2020 & 1014631021 & 515714664 & 30128739 & 184897914 & 143664174 & 53106 \\
\hline 01.08 .2020 & 1061742427 & 472631302 & 72227943 & 153215870 & 174908029 & 3608797 \\
\hline 01.09 .2020 & 1012730537 & 556782436 & 51975994 & 145925992 & 47046877 & 6258 \\
\hline 01.10 .2020 & 1175306306 & 516653441 & 51164641 & 177356325 & 149543495 & 46684 \\
\hline 01.11 .2020 & 1293371701 & 539847319 & 50537575 & 140409600 & 208258791 & 3612553 \\
\hline 01.12 .2020 & 1173028083 & 653187327 & 47657158 & 160906968 & 65803114 & 29019 \\
\hline
\end{tabular}

The proposed method of monitoring the environmental tax and other tax revenues to local budgets allowed to obtain the dynamics of revenues to the local budget of Dnipro and the dynamics of the Pearson correlation coefficient between input factors environmental tax revenues (X5), revenues of other taxes, fees and charges resulting factors. We get a similar option - insignificant values of factor X5, which require adjustment.

This once again demonstrates that the existing rates and mechanism for calculating the environmental tax do not meet modern requirements for improving the ecology of industrial regions (Kvach, Koval, Hrymaliuk, 2018).

Correlation matrix (Table 3) allows you to identify significant and insignificant factors - budget revenues. Minor factors, in particular the environmental tax, are subject to immediate transformation. 
Olga Laktionova, Zhanna Harbar, Andriy Melikhov, Olha Slobodianiuk, Volodymyr Gevko, Sergii Desiatskyi

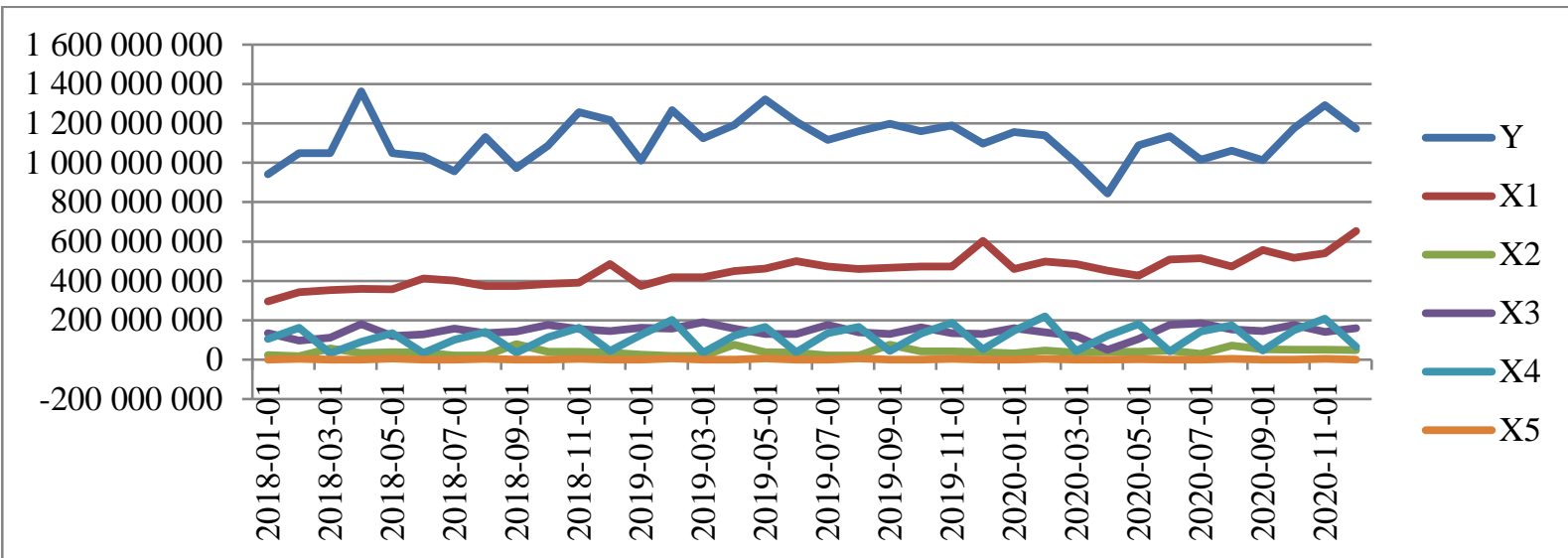

Definition: correlation coefficients between variables - revenues of the local budget and -X1-personal income tax; X2excises; X3 property tax; X4 - a single tax; X5 - environmental tax

Figure 3. Dynamics of the ecological tax (X5) in the budget of the city of Dnipro, 2018-2020, hryvnias

Table. 3 Matrix of correlations of the factor - environmental tax (X5) and others (X1, X2, X3, $\mathrm{X4)}$ with the budget revenues of Dnipro, 2018-2020

\begin{tabular}{|c|c|c|c|c|c|}
\hline & $\mathbf{X 1}$ & $\mathbf{X 2}$ & $\mathbf{X 3}$ & $\mathrm{X} 4$ & X5 \\
\hline $01.01 .2018-01.01 .2019$ & 0,3348 & $-0,0849$ & 0,4716 & 0,1652 & 0,1181 \\
\hline $01.01 .2018-01.02 .2019$ & 0,3329 & $-0,0450$ & 0,4070 & 0,1299 & 0,1443 \\
\hline $01.01 .2018-01.03 .2019$ & 0,3935 & $-0,1432$ & 0,4357 & 0,2944 & 0,2920 \\
\hline $01.01 .2018-01.04 .2019$ & 0,3949 & $-0,1521$ & 0,4100 & 0,2600 & 0,2763 \\
\hline $01.01 .2018-01.05 .2019$ & 0,4296 & $-0,0246$ & 0,4213 & 0,2721 & 0,2398 \\
\hline $01.01 .2018-01.06 .2019$ & 0,5183 & $-0,0138$ & 0,3175 & 0,3536 & 0,3663 \\
\hline $01.01 .2018-01.07 .2019$ & 0,5257 & $-0,0171$ & 0,2853 & 0,2854 & 0,3272 \\
\hline 01.01.2018 - 01.08.2019 & 0,4925 & $-0,0142$ & 0,2678 & 0,2807 & 0,3254 \\
\hline $01.01 .2018-01.09 .2019$ & 0,4933 & $-0,0257$ & 0,2610 & 0,2883 & 0,3279 \\
\hline $01.01 .2018-01.10 .2019$ & 0,5067 & 0,0376 & 0,2368 & 0,2418 & 0,2999 \\
\hline $01.01 .2018-01.11 .2019$ & 0,5040 & 0,0406 & 0,2428 & 0,2465 & 0,2876 \\
\hline $01.01 .2018-01.12 .2019$ & 0,5125 & 0,0454 & 0,2283 & 0,2668 & 0,3024 \\
\hline $01.01 .2018-01.01 .2020$ & 0,3773 & 0,0447 & 0,2346 & 0,2739 & 0,3080 \\
\hline $01.01 .2018-01.02 .2020$ & 0,3795 & 0,0415 & 0,2381 & 0,2771 & 0,2987 \\
\hline $01.01 .2018-01.03 .2020$ & 0,3725 & 0,0426 & 0,2369 & 0,2614 & 0,2971 \\
\hline $01.01 .2018-01.04 .2020$ & 0,3148 & 0,0433 & 0,2770 & 0,3012 & 0,3187 \\
\hline $01.01 .2018-01.05 .2020$ & 0,2485 & 0,0293 & 0,4761 & 0,2515 & 0,3400 \\
\hline $01.01 .2018-01.06 .2020$ & 0,2484 & 0,0283 & 0,4724 & 0,2349 & 0,3301 \\
\hline $01.01 .2018-01.07 .2020$ & 0,2481 & 0,0307 & 0,4660 & 0,2225 & 0,3234 \\
\hline $01.01 .2018-01.08 .2020$ & 0,2006 & 0,0441 & 0,4012 & 0,2019 & 0,3364 \\
\hline $01.01 .2018-01.09 .2020$ & 0,1901 & 0,0117 & 0,3940 & 0,1816 & 0,3167 \\
\hline $01.01 .2018-01.10 .2020$ & 0,1293 & $-0,0094$ & 0,3868 & 0,2067 & 0,3296 \\
\hline $01.01 .2018-01.11 .2020$ & 0,1462 & 0,0031 & 0,3973 & 0,2157 & 0,3139 \\
\hline $01.01 .2018-01.12 .2020$ & 0,2025 & 0,0332 & 0,3763 & 0,2737 & 0,3429 \\
\hline
\end{tabular}

The proposed method of monitoring the processing of data sets, including environmental tax by methods of predictive analysis, allowed to obtain the dynamics of
Pearson's correlation coefficients between tax revenues, including between environmental tax and local budget revenues of Dnipro (Table 3, Fig. 4). 


\section{sciendo}

Management Theory and Studies for Rural Business and Infrastructure Development eISSN 2345-0355. 2021. Vol. 43. No. 4: 574-584

Article DOI: https://doi.org/10.15544/mts.2021.52

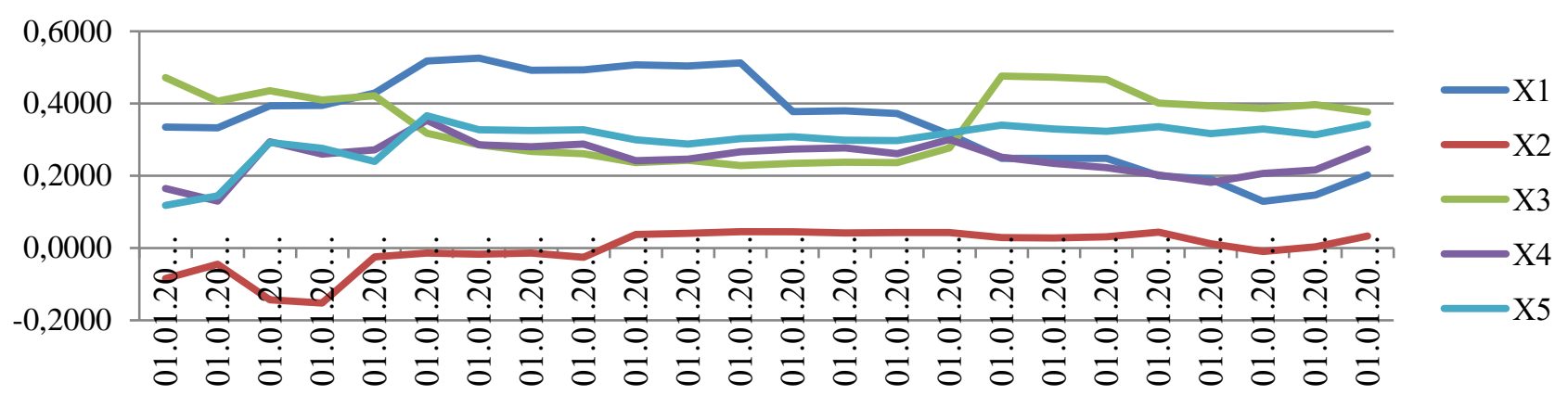

Figure 4. Dynamics of Pearson correlation coefficients between environmental tax revenues and local budget revenues of Dnipro, 2018-2020

Algorithm proposed of the analytical system for managing environmental tax revenues to local budgets (Fig.5).

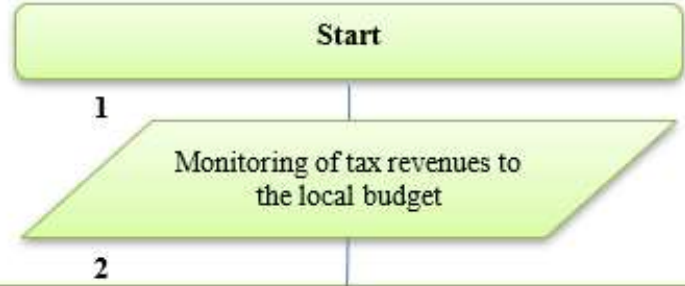

Predictive analysis of taxes in the local budget. Environmental tax by components: environmental energy taxes; transport taxes; taxes for environmental pollution.

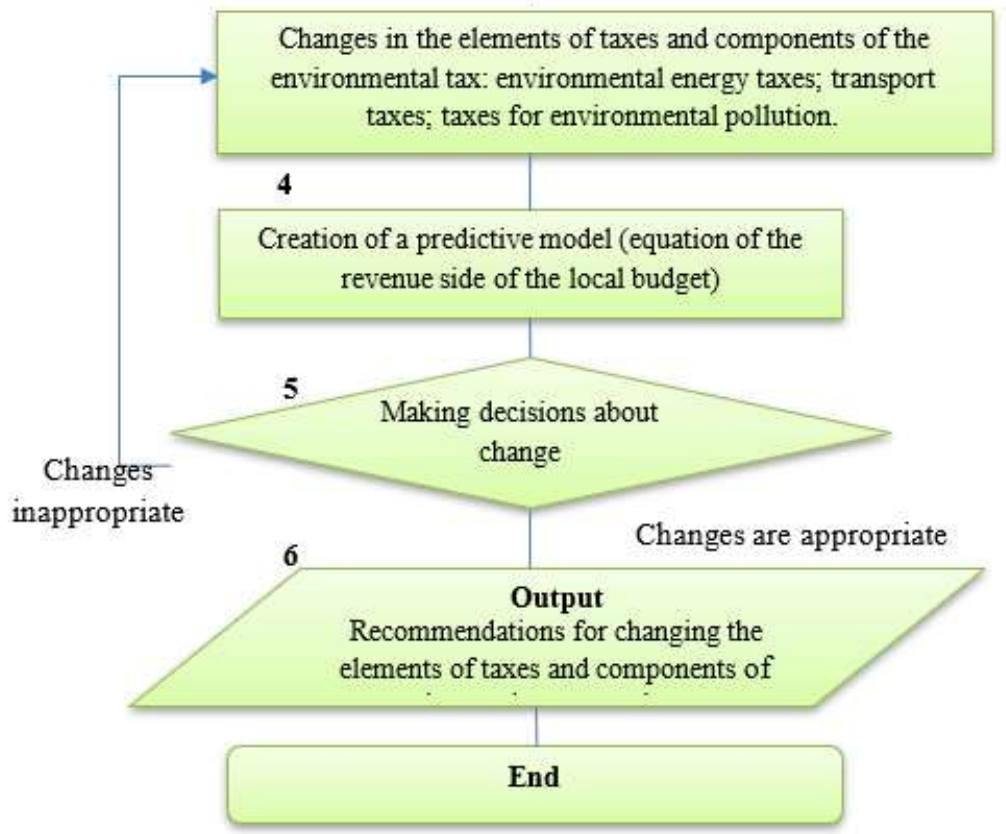

Figure 5. Algorithm of the analytical system for managing the revenues of the environmental tax of enterprises in the industrial regions of Ukraine in the context of sustainable development 
It was revealed that the development and implementation of greening projects in industrial regions, especially with metallurgical production, require additional funding, which is not provided for in the plans of metallurgical plants. One of the important projects of greening of regions today is the project on monitoring of structure of atmospheric air, including definition of harmful emissions. For the implementation of this project and subsequent work, it is proposed to reduce costs and improve the quality of management of tax revenues to the revenue side of local budgets. For this purpose, a method of processing data sets from monthly receipts in Openbudget was proposed. A toolkit of predictive analytics correlation analyzes was proposed to identify significant and insignificant factors - revenues to local budgets. It was suggested either to transform insignificant factors by changing tax rates within the framework of the legislation, or to abandon them. Data processing was performed using analytical systems. The method was tested on the revenues of local budgets of cities with metallurgical production - Zaporizhzhya, Dnipro for the period 20182020. The use of the methodology allowed to show that the revenues of the environmental tax are the most insignificant. It is also proposed to use the experience of developed countries in the mechanism of calculating the environmental tax in order to increase its amount.

\section{Conclusions}

The ecological situation of industrial regions, including the metallurgical production of Ukraine, requires immediate improvement. It is necessary to develop and implement projects aimed at monitoring and cleaning of air, water and land from pollution. However, the existing rates, the mechanism for calculating the environmental tax does not allow to raise enough funds to implement environmental measures. The quality development and implementation of environmental projects requires sufficient financial resources, the lack of which does not allow for the greening of industrial regions. The paper proposes a method of identifying significant and insignificant factors - revenues in the resulting factor - the total revenue of local budgets. Minor factors can be transformed by changing rates because they are abandoned and replaced by others within the law. The proposed methodology allows for monthly monitoring of local budgets (environmental and other taxes, fees and charges) by processing Openbudget data. Implement a flexible response to the environmental tax by changing the rate within the law. The monitoring methodology will not lose its relevance even after the necessary transformation of the environmental tax.

Data processing was performed using analytical systems. The method was tested on the revenues of local budgets of cities with metallurgical production - Zaporizhzhya, Dnipro for the period 2018-2020. The analysis showed that the most dynamics of the environmental tax to the budget of the city of Dnipro was personal income tax (X1), and to the budget of the city of Zaporozhye personal income tax (X1) and property tax (X3). The use of the methodology allowed to show that the revenues of the environmental tax are the most insignificant. It is also proposed to use the experience of developed countries in the mechanism of calculating the environmental tax in order to increase its amount.

\section{References}

Bolshina, E.P. (2012). Ecology of metallurgical production: Course of lectures. Novotroitsk: NF NITU «MISiS»

Dnipro City Council (2021). Open budget of Dnipro. https://dniprorada.gov.ua/uk/articles/category/rishennya-promiskij-byudzhet

Dotsenko, E., Ezdina, N., \& Mudrova, S. (2018). Ecologization of Regional Industrial Complex in the Transition to Sustainable Development. E3S Web of Conferences, 41, 04050.

Draper, N., \& Smith, H. (2007). Applied Regression Analysis. Multiple Regression. M.: Dialectics.

Filin, A. E., Zinovieva, O. M., Kolesnikova, L. A., \& Merkulova, A. M. (2018). Prospects of safety control in combination of mining and metallurgy industries. Eurasian Mining, (1), 31-34. 
Glushchenko, A. (2021). Gmk.center. Environmental taxation in Ukraine and the EU: similarities and differences. https://gmk.center/posts/ekologicheskoe-nalogooblozhenie-v-ukraine-i-es-cherty-shodstva-i-razlichiya/

Gubanova E., Kupinets L., Deforzh H., Koval, V., \& Gaska K. (2019). Recycling of polymer waste in the context of developing circular economy. Architecture Civil Engineering Environment, 12(4), 99-108. doi: 10.21307/ACEE-2019055

Jishkariani, G., Mikaberidze, M., Sakhvadze, D., \& Tavadze, G. (2010). Cleaning-Reduction of the Soils Polluted by Heavy Metals via the Phytoremediation Method. Ceorgia Chemical Journal, 10(4), 95-105.

Korshunov, Y. A., Lisienko, V. G., Tretyakov, V. S., Burkin, S. P., \& Serebryakov, A. V. (2012). New technology of carbon- free metal production with high- strength nanocrystalline structure for nuclear power. International Journal of Energy for a Clean Environment, 13(1-4).

Kostetska, K., Gordiichuk, Y., MovchaniukA., Vdovenko, N., Nahornyi, V., \& Koval, V. (2021). Inclusive development of social entrepreneurship in nature management. Journal of Geology, Geography and Geoecology, 30(3), 500-511. https://doi.org/https://doi.org/10.15421/112146

Kostetska, K., Smol, M., \& Gaska, K. (2018). Rational nature use of recreational management subjects on the basis of inclusive. Economics Ecology Socium, 2(4), 31-40. https://doi.org/10.31520/2616-7107/2018.2.4-4

Kvach, Y., Koval, V., \& Hrymaliuk, A. (2018). Tourism and hospitality industry in the context of global economic development. Economics Ecology Socium, 2(4), 11-21). https://doi.org/10.31520/2616-7107/2018.2.4-2

Kvach, Y., Piatka, N., \& Koval, V. (2020). Management of sustainable entrepreneurship adaptation to tax changes in environmental investment. Baltic Journal of Economic Studies, 6(5), 96-105. https://doi.org/10.30525/22560742/2020-6-5-96-105

Meshram, P., \& Pandey, B. D. (2019). Perspective of availability and sustainable recycling prospects of metals in rechargeable batteries-a resource overview. Resources Policy, 60, 9-22.

Mikelsone, E., Atstaja, D., Koval, V., Uvarova, I., Mavlutova, I., \& Kuzmina, J. (2021). Exploring Sustainable Urban Transformation Concepts for Economic Development. Estudios de Economia Aplicada, 39 (5). https://doi.org/10.25115/eea.v39i5.5209

Saxena, R. P., \& Kumar, B. R. (2020). Greening for sustainability: green UAE-a classic example. Interdisciplinary Environmental Review, 20(2), 118-135.

Tax Code of Ukraine (2014). Customs Code of Ukraine. K.: SOE «SPC MinRD of Ukraine».

Zaporizhzhia City Council (2021). Open budget of Zaporizhzhya. https://zp.gov.ua/uk/page/gromadskij-byudzhet

Zhang, W., Zhang, M., Wu, S., \& Liu, F. (2021). A complex path model for low-carbon sustainable development of enterprise based on system dynamics. Journal of Cleaner Production, 321, 128934. 